\title{
LKPD Development On MEAs Based-Approach to Improve the Mathematical Representation Ability of Grade X Students
}

\author{
Riren Rostari ${ }^{1^{*}}$, Irwan $^{2}$, Yulkifli ${ }^{3}$ \\ ${ }_{1,2,3}$ Universitas Negeri Padang, Padang, Indonesia \\ *Corresponding author, e-mail: rostaririren@gmail.com
}

\begin{abstract}
LKPD used in school had not been optimal in helping students to improve the mathematical representation ability. It happened because the used LKPD was giving a less opportunity to the students to solve the mathematical representation problems. One of the solutions to do about that problem is to develop LKPD-Modeling Eliciting Activities (MEAs) based approach. The purpose of this study is to produce a valid, practical and effective LKPD-MEAs based approach to improve the students' mathematical representation. This study is a development research using Plomp model which consists of Preliminary Research, Development or Prototyping and Assessment Phase. The subjects of this study were $\mathrm{X}$ grade students of SMAN 3 Padang. The instruments used were LKPD validation sheets, teacher's response questionnaires, students' response questionnaires and test. The result of this study is a valid, practical and effective LKPD-MEAs based approach with an average of each is $0,728,85,39$ and 82,41 .
\end{abstract}

Keywords: MEAs, LKPD, Representation abylity, Plomp.

How to Cite: Rostari, R., Irwan, I., \& Yulkifli, Y. (2017). LKPD Development On MEAs BasedApproach to Improve the Mathematical Representation Ability of Grade X Students. International Journal of Research in Counseling and Education, 1(1), 27-36. https://doi.org/10.24036/0010za0002

This is an open access article distributed under the Creative Commons 4.0 Attribution License, which permits unrestricted use, distribution, and reproduction in any medium, provided the original work is properly cited. (2017 by author and Universitas Negeri Padang.

\section{Introduction}

Mathematics is one of the important science in education development. Those developments include all aspects of human life, start from agriculture, trade, industry, population even in political science. Therefor, mathematics is also used by the other disciplines as a suplemantary science, such as Natural Sciences and Social Sciences.

Since mathemathics is very importance, this subject is become taught in all levels of education ranging from elementary school to university with the total hours of the lessons more than the other subjects. This is done in order to equip the students with mathematical thinking skills such as mathematical problem solving, mathematical reasoning, mathematical representation, mathematical connections, and mathematical communication NCTM (2000).

One of the purposes of mathematics learning through the Regulation of National Minister of Education Number 21 in 2016 as stipulated in the Education Content Standard of Elementary Schools to Senior High Schools is to determine the proficient ability or the proficiency to communicate the ideas or mathematics' ideas by using symbols, tables, graphs or diagrams to clarify the situation or mathematics' problems. A similar thing is also expected in mathematics learning, NCTM (2000) developing and understanding the 
concept of mathematics is deeper by using symbols, tables, graphs or diagrams. Furthermore, NCTM (2000) named it with mathematical representation.

Mathematical representation is very important for the students because it helps them to a concept of mathematics. It is not only good for the students' understanding, representation also helps them in applying mathematics to the real problem situations through modeling (NCTM, 2000). In addition, representation also can make us easier to find a problem solving. According to Brenner (Neria \& Amit, 2004) the success of problem solving depends on: (1) the skills of representing problems such as constructing and using mathematical representations in terms of words, graphs, tables and equations; (2) solve the problems; and (3) manipulate the symbols.

Based on the results of a study conducted on VIII grade students of Junior High School (SMP) by Trends International Mathematics and Science Study (TIMSS) which was organized by International Association for the Evaluation of Educational Achievement (IEA) in 2011 in mathematical ability, Indonesia was ranked $38^{\text {th }}$ of 42 participating countries. Indonesia's score was 386 from the International average score was 500. The average percentage score of Indonesian students on the representation questions was $23 \%$ (Mullis, at all, 2012). Based on the achievement scores in the TIMSS study, it can be seen that the ability of mathematical representation of Indonesian students is still low.

The students' low ability of representation can be seen from some researches, such a research by Tusaddiah (2012), this research finds that the quality of the students' mathematical representation ability is not satisfactory, it is about $30 \%$ and $32 \%$ of the ideal score. In addition, Amri (2009) states that the students are never given the opportunity to present their own representations which can enhance their representational skills in mathematics learning, the students tend to imitate the teacher's procedures. Hudiono (2005) also shows the occurrence of students' weakness of representation. Tables, drawings, and models were presented to the students only as a complement in delivering the materials, the teachers were less likely to develop the students' representational skills. Based on preliminary study conducted at SMAN 3 Padang, SMAN 7 Padang and SMAN 12 Padang on September 2017 by giving the representation skills test, interviewing by the teacher, students' questionnaires and learning activities observations. The analysis test result of representation ability test of the students obtained that the average percentage is $54,17 \%, 50 \%$ and $51,12 \%$. This shows that the students' representation ability are still relatively low.

The observations and interviews result with the teachers in the classroom showed that the students' representation ability is still low. According to the teachers' interviews obtained information that when it is viewed from the indicators of mathematical representation ability which includes visual representation, mathematical expressions representation and verbal representation is still not fully developed. Furthermore, the students' questionnaires results in mathematics learning in preliminary analysis is similar to the results of teachers' interviews which shows less development of students' representation ability. The representations such as tables, graphs and images are only as a companion or complement in delivering the material.

Based on the problems showed above, it is should be done the improvement of mathematics learning immediately, especially related to the representation ability due to the achievement of mathematics learning's goals and target. The main duty of the teachers in the constitution No. 22 in 2016 is to plan the learning by elaborating the subject matter so that it becomes a developed and easy to understand the teaching material. The teachers as professional educators are expected to have the ability to develop teaching materials in accordance to the determined mechanism by paying attention to the students' characteristics and social environment.

Based on the interviews' results with teachers, obtained information that teachers have not made and develop teaching materials in accordance with the Ministerial Decree No. 24 in 2016 curriculum 2013 which can facilitate students to improve their representation ability because teachers still depend on common LKPD. According to the teacher, the sub-topic sequence of the material in LKPD used is not in accordance to the Ministerial Decree Number 24 in 2016 Curriculum 2013, the questions in LKPD have not varied and structured from easy to difficult questions yet and the language logic in LKPD is also not 
communicative yet to guide the students in answering the questions. Then, the students' questionnaire results obtained that students have difficulties in using LKPD such as; difficulties in understanding materials, understanding questions and developing ideas in answering questions because the languages used in LKPD is still difficult to understand by students and not communicative yet to guide students in answering the questions.

Based on the analysis of LKPD at X grade of SMAN 3 Padang, SMAN 7 Padang, and SMAN 12 Padang, it is known that the presentation of the material has not been referring to the Ministerial Decree Number. 24 in 2016 Curriculum 2013. Such a presentation of material in LKPD on the material function shown in Figure 1.

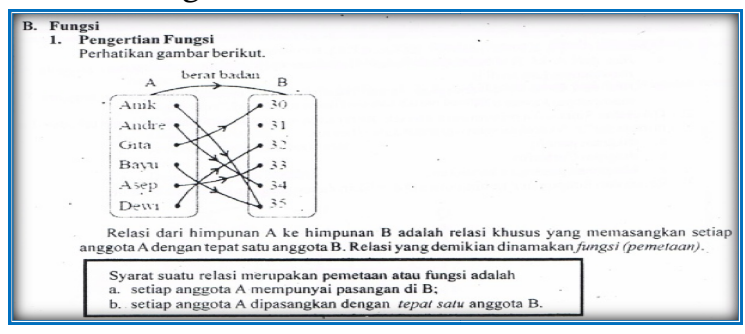

Figure 1. Example of Presentation of LKPD Materials

In Figure 1. it appears that LKPD has not fully addressed a real problem which involve students modeling into mathematics to solve mathematical problems. In this function material, students should be given real problems in their environment, then provide opportunities for students to model into the arrow diagram, cartecius diagram or paired sequence. After that, students are asked to express their understanding related to the concept of Function. However, in this LKPD there are no steps that must be taken by students to model real problems into diagrams of arrows, cartecius charts or sequential pairs. That LKPD makes students are more likely to memorize the concept than to develop and understand the concept. Therefore, it is needed LKPD which leads students to construct real problems into mathematical models.

A learning approach which can relate mathematical ideas to the environment of daily life with mathematical models is Model Eleciting Activities (MEAs). As stated by Lesh and Doerr (2003), MEAs is a learning approach which begins by presentation of problem situations that elicits activities which produce mathematical models used to solve mathematics problems. MEAs learning purpose is to observe the progress of concept mastery and the growth of students' mathematics understanding (Besterfield, 2010: 9). While Eric (2008: 3) argues that "the use of MEAs promises the mathematics basic concepts in the thinking processes and students problem solving and can help them move beyond primitive thinking.

The Curriculum 2013 Implementation outlines the scientific approach in the learning process. The scientific approach in such learning involves observing, asking, trying, processing, presenting, summarizing, and creating. In Permana's research (2007) explains that MEAs provide tremendous opportunities for a scientific approach to explore knowledge in mathematics learning. MEAs with a scientific approach is a learning where students make observations of the problems given, then they respond the problem by asking questions. Then students discuss the solution in groups by making the mathematical model as a conclusion, then students present the discussion results in front of the class. Hanifah (2015) concludes that the achievement and improvement of students' mathematical representation ability who gain learning MEAs by scientific approach is better than students who gain learning with scientific approach only.

Interviews results with teachers showed that the learning activity begins with the introduction of the concept. When it is applied, students tend to be difficult when they were facing with the contextual problems. Students were often mistaken when representing problems into mathematical models such as graphs, tables and equations for answering questions. Therefore, with an eye to students representing their ideas properly it is needed in the learning process which leads students modeling the problem to the mathematical model. Based on the description above, researchers will conduct. A research on LKPD development on MEAs based approach. 
The formulation of the problem in this study "How are LKPD characteristics on a valid, practical and effective MEAs based approach to improve the students' mathematical representation in mathematics learning of grade X SMA?". The purpose of this research is to describe LKPD characteristics on valid, practical and effective MEAs based approach to improve the students' mathematical representation in mathematics learning of grade X SMA.

\section{Method}

The type of this research was a development research by using Plomp model. The development was done on LKPD of MEAs based approach to improve the mathematical representation ability of grade $\mathrm{X}$ high school students. The Plomp model starts from the preliminary research phase, the prototyping phase, and the assessment phase (Plomp and Nieveen 2013: 30). The preliminary research phase consists of needs analysis, curriculum analysis, concept analysis, learner analysis. In prototyping phase, making this prototype is conducted by formative evaluation. The prototyping phase consists of prototype 1, selfevaluation and expert review; prototype 2, is the result of one-to-one evaluation; prototype 3 , is small group evaluation, and prototype 4 is the result of formative evaluation. In the assessment phase, field testing was conducted in X-SMAN 3 Padang to see the practicality and effectiveness. The research data was collected through validation sheet, teacher response questionnaire and student response questionnaire, and the result of students' representation ability test. Instrument validation was done by three Mathematics lecturers, one Language lecturer, and one Education Technology lecturer of Universitas Negeri Padang (UNP).

\section{Results and Discussion}

\section{Preliminary Research Results}

At this phase, identification or analysis was required for LKPD development on MEAs based approach. This phase was done by analyzing the objectives within the boundaries of the subject matter to be developed. There were four basic steps that must be done, namely: a. Needs Analysis

At this phase conducted the information collection about the problems of mathematics learning. The information collection was done through observation of learning activity, interviewing mathematics teacher, filling in questionnaire by students and representation ability test. Based on observations and interviews with mathematics teachers indicated that the need of students are new learning approaches apart from conventional learning commonly used in schools which are more capable to optimize the students' mathematical representation ability. Based on the initial test results of students' representation ability obtained the conclusion that the students' mathematical representation ability is still not fully developed. The MEAs approach is chosen because the learning approach involves the learner actively, and provides the opportunity for the students to solve the mathematical representation problem.

Based on the interviews with teachers, the available LKPD had not fully facilitated the students to improve their representation abality and from the information obtained that teachers had not created and developed the teaching materials yet in accordance to the Ministerial Decree Number 24 in 2016 Curriculum 2013, since the teachers were still dependent on the common existing LKPD. Therefore, the learning instrument needed are LKPD that can improve the students' mathematical representation in grade $\mathrm{X}$ of senior high school.

Apart from doing interviews with teachers and giving the representation skills test, the researchers also conducted questionnaires to 36 students about the characteristics of LKPD. Based on the questionnaire result, it can be concluded that the LKPD wanted by the students is a LKPD which some interesting pictures, LKPD is dominant in blue, LKPD which is written with Cambria Math type, the LKPD size is regular and common and LKPD is variated.

\section{b. Curriculum Analysis}

In this phase conducted an analysis of Curriculum 2013 for compulsory mathematics subjects in grade $\mathrm{X}$ of Senior High School/ MA semester 1. This analysis is necessary to learn about the material and 
learning purposes for each LKPD meeting. Aspects that are considered in analyzing the curriculum are Core Competence (KI) and Basic Competence (KD) aspects. The results of $\mathrm{KI}$ and $\mathrm{KD}$ analysis are elaborated into achievement indicator of competencies in order to make students understand easier. There are six KD that will be translated to achieve the optimal learning purposes in the analysis results of compulsory mathematics subjects of KI and KD grade X SMA/ MA semester I, they are KD 3.1,4.1; KD 3.2, 4.2; KD 3.3, 4.3; $\mathrm{KD} 3.4,4.4 ; \mathrm{KD} 3.5,4.5$ dan $\mathrm{KD}$ 3.6,4.6.

\section{c. Concept Analysis}

Conceptual analysis aims to determine the content and subject matter needed in the LKPD development by identifying key concepts which is taught, detailing and arranging them systematically according to the order of presentation. The results of concept analysis based on the curriculum 2013 on compulsory mathematics of class X SMA semester I, have 6 chapters studied, they are; (1) equations and inequality of absolute value of one variable, (2) rational and irrational inequality one variable, (3) system of linear equation three variable, (4) inequality systems of two variables (linear-squares and squares), (5) functions and (6) the composition of functions and inverse functions.

\section{d. Students Analysis}

This analysis aims to determine the quality of individuals which can be used as a guidance in designing LKPD. Activities conducted are identifying characteristics of students including academic ability, students 'learning trends and students' preference toward color to design learning instruments. The analysis was conducted on the students of grade X SMAN 3 Padang SMA 7 Padang and SMA 12 Padang in 2017/ 2018 by spreading the questionnaire to students.

The results of the questionnaire indicated that many students are less fond of mathematics land consider mathematics a difficult subject. Students prefer to learn in groups. This characteristic indicates that students prefer to do an activity together. Students also need learning resources in the form of LKPD which is dominant in blue color with A4 paper size and accompanied by interesting drawing in accordance to the material, the implementation of learning steps are directed and clear, so that students can understand the material and solve problems in groups.

\section{Prototyping Phase Results}

a. Designing the LKPD

1) The Didactic Aspect

The material presentation began by giving problems in daily life related to the material which is being studied. To attract students attention more, they were given some appropriate picture that was expected could help students understand the problem given. This phase named as Reality principle on MEAs based approach. One of the examples on Reality principle in LKPD is shown in Figure 2.

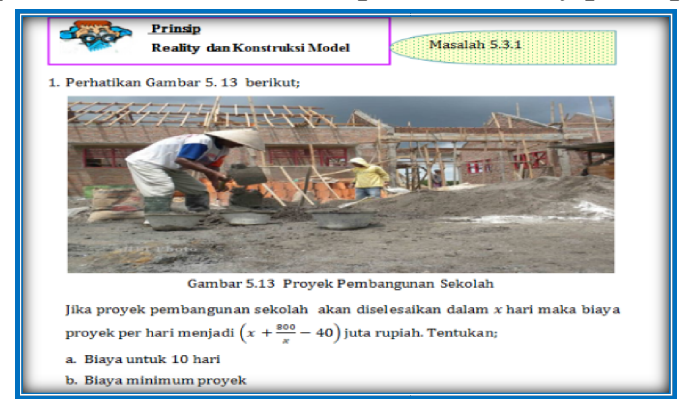

Figure 2. LKPD Reality Principle

After understanding about the problem, students were independently asked to solve the problem according to their own knowledge and questions to be answered or guidance given. Through these instructions, students could explore the ideas they have to find the mathematical model from the problem. The presented ideas could be written on the box provided. Then, students discussed in their group so that they could equate the idea in answering questions or doing some commands given. This could make students actively involved in solving problems. In this process teachers were also involved to lead students in modeling and solving problems. This phase called as Construction Model Principle on MEAs based approach. The example of LKPD Construction Model principle shown in Figure 3. 


\section{Kamu sudah menyelesaikan Masalah 5.1.1 kan? sekarang silahkan kamu \\ berdiskusi dengan teman sekelompokmu dan bandingkan pendapatmu tentang penyelesaian Masalah 5.1.1 dengan pendapat teman sekelompokmu. Apabila pendapatmu ada yang berbeda maka diskusikanlah dan tulis hasil diskusinya pada kotak yang telah disediakan di bawah ini!}

\section{Figure 3. LKPD Construction Model Principle}

After doing the activities in the LKPD, students were asked to write down the results of their group discussions on the boxes provided. Furthermore, students presented their discussion results in front of the class to check the correctness of their work (the truth of presenting and the correct solution to be a solution). If there was a mistake in solving the problem in accordance to the the questions, students could improve their work then. This presentation activity is a self-assessment principle in MEAs approach. The example of LKPD Self-assessment Principle shown in Figure 4.

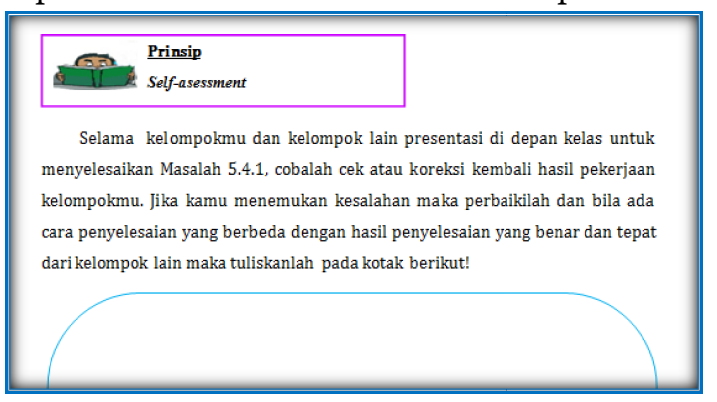

\section{Figure 4. LKPD Self Assessment Principle}

After checking the solution of the problem, the next principle is the Model Documentation where students express their thoughts during work and their thought processed into a documentation in the form of solutions written on the box that had been provided. This activity is the documentation principle of the MEAs based approach. Here is an example of the model documentation principle shown in Figure 5.

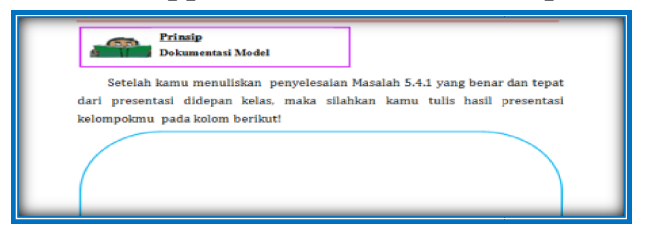

\section{Figure 5. Model Documentation Principles}

The next principle is Effective Sharing and Prototype. This is to discuss other problems that aims to see the level of understanding of students about the material that had been studied. The solution of this problem was the same basic structure with Reality problem that had been resolved. This following example is an effective Sharing and Prototype principles which is shown in

$$
\text { Figure } 6 .
$$

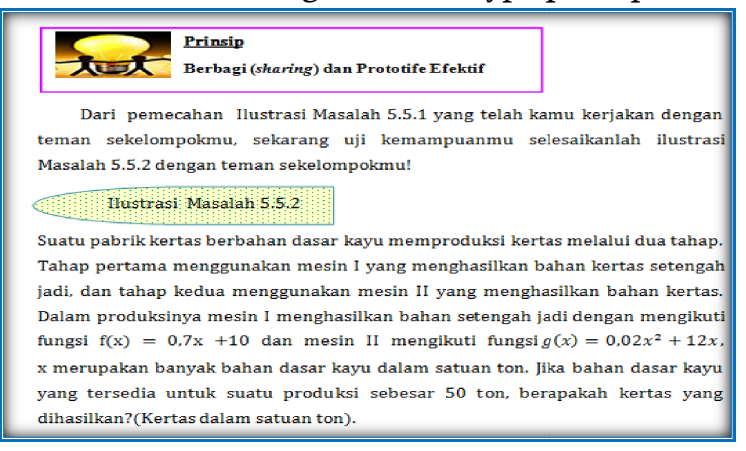

\section{Figure 6. LKPD Effective Sharing and Prototype Principles}

\section{2) Aspects of Content}

The materials using MEAs based approach are presented in accordance with the indicators of competence achievement. For example, to achieve an "indicator explains the meaning of relations 
formally" students are faced in observing car parking costs in the airport area with the purpose is that the students can explain the relationship of time spent and the parking cost is a relation. Learning activities are equipped with instructions on the steps which must be done clearly by the students following by pictures in order to make learning process goes meaningful, interesting and fun.

\section{3) Display}

The LKPD display is made as attractive as possible, consist of a LKPD cover (cover) which is a blend of blue, yellow, and white. This color is chosen because based on the preliminary analysis, the students prefer blue as their favorite. Then, The LKPD component consists of introduction, table of contents, instructions on the use of LKPD, introduction, chapter title, KD, indicators and learning purposes, material descriptions, sample questions and exercises.

\section{4) Language Aspects}

The writing and language used in LKPD are in accordance with the enhanced spelling (EYD). LKPD uses a simple and communicative language such as the use of greeting "Kamu" is in accordance with the level of high school students understanding and avoid the use of terms which are difficult for them tounderstand. In addition, commands and questions on LKPD are prepared in clear sentences so as to direct students to perform activities or answer questions as expected.

\section{b. Prototype 1}

Prototype 1 is the initial phase of LKPD design result. To obtain a valid LKPD, there are two steps taken to validate the LKPD, which is self evaluation and expert review. The validation of LKPD prototype which has been designed is described below.

\section{1) Self evaluation result}

In general, errors in LKPD mostly occur in typing words and punctuation. For example, errors occur in the words "pembelajaran" written as "pemelajaran" and "dengan", written as "dengen" and the word of "sumbu" written as "sunbu". In addition, the writing of punctuation which should be "." written as ",". And also at the end of the sentence many of them are not marked by ".". So for the perfection of LKPD, it needs a revision/ repair, so that the designed LKPD does not have many errors/ not out of the expected product specifications.

\section{2) LKPD validation results by Expert}

During the validation process there are several revisions suggested by the validator. Instead of giving some suggestions, the validator also assesses the LKPD that the researcher has made. The result of LKPD validation on MEAs based approach in all aspect is generally didactic aspect validity, linguistic aspect and graph aspect have been valid with the average of validity index is 0,$783 ; 0.667$ and 0.734 . Overall, the LKPD validity on MEAs based approach has met the valid criteria with the average of the overall index is 0,728 .

\section{c. Prototype 2}

Based on observations of individual evaluations indicates that LKPD used based on the level of difficulty is corresponding with the ability of high school level. The problem given is not too difficult nor too easy. In terms of delivering the systematic materials, it has been arranged well. So, the students understand the material on LKPD quite easily. LKPD used in terms of easiness of use, readability, presentation and the practical time used. The clarity of the instructions and problems presented in the LKPD is clear as a whole. Students also said that the color design and LKPD appearance which tend to be bright and light colored make them more interested to read and understand. The questions in LKPD are corresponding with the level of students' abilities.

Based on this details of individual implementation evaluation, this revision is limited to the sentence only in general. Researchers conducted the LKPD improvements on MEAs based approach to obtain a better LKPD. The result of LKPD improvement on MEAs based approach is called as prototype 3. Furthermore, a test in small group is conducted after this evaluation of each person.

\section{d. Prototype 3}

The results of small group observation analysis illustrate that they enjoy studying by using LKPD on MEAs based approach. In terms of easiness of use, LKPD is easy to use, students can understand the learning materials by using LKPD well. In terms of legibility, students can understand the language used 
in LKPD easily, so that they can identify problems and do the commands or answer the questions on LKPD.

The results of the next observation analysis, the learning process activities by using interesting LKPD, the images presentation and illustrations in LKPD facilitate them to understand the concept of material. Further learning steps are using MEAs based approach, students show a good progress of involvement in the learning process such asking questions and discussion actively.

\section{Results of the Assessment Phase}

The assessment phase is a prototype phase 4, done by doing field test in grade X of SMAN 3 Padang to see the effectiveness and effectiveness of LKPD based on MEAs approach. The following describes the practicality and effectivity of LKPD on MEAs based approach;

\section{a. LKPD Practicality on MEAs Based Approach}

Practicality Questionnaires are given to students and teachers after attending all learning which is using MEAs based approach LKPD. According to the students' response of LKPD practicality test results on MEAs based approach can be seen in Table 1 .

Table 1: Student Response Questionnaire Results toward MEAs based Approach LKPD

\begin{tabular}{|c|c|c|}
\hline Rated Aspecs & $\begin{array}{c}\text { Practicality } \\
\text { Value (\%) }\end{array}$ & Category \\
\hline The Attractiveness & 84,03 & Practical \\
\hline The Usage Process & 82,12 & Practical \\
\hline The Easiness of Use & 82,99 & Practical \\
\hline The Time & 76,39 & Practical \\
\hline Overall Average & $\mathbf{8 2 , 5 3}$ & Practical \\
\hline
\end{tabular}

In Table 1., according to the response of students, it is seen that the average LKPD level of practicality on MEAs based approach is $82,53 \%$. Thus, it can be concluded that LKPD-based approach to MEAs is practical.

Table 2: Teachers Response Questionnaire toward MEAs Based Approach Mathematich LKPD

\begin{tabular}{|l|c|c|}
\hline \multicolumn{1}{|c|}{ Rated Aspecs } & $\begin{array}{c}\text { Practicality } \\
\text { Value (\%) }\end{array}$ & Category \\
\hline The Attractiveness & 81,25 & Practical \\
\hline The Usage Process & 90,00 & Practical \\
\hline The Easiness of Use & 95,83 & Practical \\
\hline The Time & 75,00 & Practical \\
\hline Overall Average & $\mathbf{8 8 , 2 4}$ & $\begin{array}{c}\text { Very } \\
\text { Practical }\end{array}$ \\
\hline
\end{tabular}

b. In Table 2., the result of teacher response questionnaire is 88,24 . Based on predefined categories, the LKPD on MEAs based approach is considered very practical. Overall, based on both students and teachers questionnaire result, the practicality is 85,39 with category very practical.

\section{b. LKPD Effectiveness on MEAs Based Approach}

The effectiveness of LKPD is seen from the result of students mathematical representation test after studying by using LKPD on MEAs based approach. Prior to the final test of the field test class, this final test is tried on different classes to see the validity, distinguishing and difficulty index. The trial of this final test was carried out in a different class. It was on X.8 class MIA SMAN 3 Padang which amounted to 25 students. Based on the test results obtained that all questions are valid, good distinguishing power, and a good difficulty index.

After the final test question is tested in different class then the final test is held in the field test class. The effectiveness of LKPD MEAs based approach is also seen from the acquisition of students mathematical representation ability test scores in Table 3.

Table 3: Percentage of Test Score Achievement Ability of Students Mathematical Representation.

\begin{tabular}{|l|l|}
\hline Representation Ability & Percentage of ideal \\
\hline
\end{tabular}




\begin{tabular}{|l|c|}
\hline Indicators & scores \\
\hline Visual & $83,33 \%$ \\
\hline Verbal & $72,22 \%$ \\
\hline $\begin{array}{l}\text { Mathematical } \\
\text { Expression }\end{array}$ & $91,67 \%$ \\
\hline Average & $\mathbf{8 2 , 4 1 \%}$ \\
\hline
\end{tabular}

Based on the analysis results of mathematical representation test above obtained an average percentage $82.41 \%$, with very good category. So it can be concluded that MEAs based approach LKPD is effective to improve the students mathematical representation ability.

\section{Conclusion}

This research is a development research which produces MEAs based approach LKPD. Based on the research, it can be concluded that (a) LKPD development process on MEAs based approach in grade X of high school students which correspond with Plomp development model consist of three phases: initial investigation phase, development phase and assessment phase. Based on the development process, the results obtained in form of MEAs based approach LKPD in grade $\mathrm{X}$ of high school students is valid both in terms of content and construction, practical both from the aspect of implementation, easiness and time required, effective to improve the students mathematical representation ability.

There are some suggestions from the based on the conclusions of this research, they are, (a) this is can be used by mathematics teachers as an alternative LKPD for grade X (b) it is hoped that there will be further tests in other schools to see the wider practicability and effectiveness of the developed LKPD c) For researchers who continue this research, it is advisable to innovate in subsequent research.

\section{Acknowledgment}

As the completion of this research, the researcher would like to thanks to all those who have helped the adviser; Rector of Universitas Negeri Padang (UNP); Ministry of Research, Technology and Higher Education UNP through DIPA UNP Fiscal Year 2017 No.1618/UN35.2/PG/2017; the principal of SMAN 3 Padang; mathematics teachers and students of SMAN 3 Padang so that this research can be done properly.

\section{References}

Amri. 2009. Peningkatan Kemampuan Representasi Matematis Siswa SMP melalui Pembelajaran dengan Pendekatan Induktif-Deduktif. Disertasi tidak diterbitkan. Bandung: Program Pascasarjana UPI.

Besterfield, M. et al. 2010. Model Eliciting Activities: Assessing Engineering Student Problem Solving and Skill Integration Processes. International Journal Enginering Education Vol.26, no.4, pp.831-845. University of Pittsburgh.

Eric, M. 2008. "Using Model Eliciting Activities For Primary Mathematics Classrooms". International Journal of The Mathematics Educator, Vol. 11, No.1/2, 47- 66. National Institute of Education, Nanyang Technological University, Singapore.

Hanifah (2015).Penerapan Pembelajaran Meas Dengan Pendekatan Saintifik Untuk Meningkatkan Kemampuan Representasi Matematis Peserta Didik. Skipsi tidak diterbitkan. Jawa Barat: FKIP UNSIKA.

Hudiono, B. (2005). Peran Pembelajaran Diskursus Multi Representasi terhadap Pengembangan Kemampuan Matematik dan Daya Representasi pada Peserta didik SLTP.Disertasi pada PPS UPI.

Lesh, Richard, and Doerr, Helen M. 2003. Beyond Constructivism: Models and Modeling Perspectives on Mathematics Problem Solving, Learning, and Teaching. New Jersey: Lawrence Erlbaum Associates Publishers.

Mullis, I.V.S., Martin, M.O., Foy, P., \& Arora, A. 2012. TIMSS 2011 Internastional Result inMathematics. Chestnut Hill, MA: TIMSS \& PIRLS International Study Center, BostonCollege. 
NCTM. (2000). Principles and Standards for School Mathematics. Curriculum and evaluation Standards for School Mathematics. Reston, VA: Author.

Neria, D. \& Amit, M. 2004. Students Preference of Non-Algebraic Representation in Mathematical Communication.Dalam T. Nakahara \& M. Koyama. (Eds). Proseeding of the 28thConferenceof the International Group for the Psychology ofMathematicsEducation [Online],Vol.3.

Peraturan Menteri Pendidikan Nasional 2016. Jakarta: Kemendikbud.

Permana, Y dan Sumarmo, U. (2007). Pengembangan Kemampuan Penalaran Dan Koneksi Matematik Peserta didik SMA Melalui Pembelajaran Model Eliciting Activities.Educationist.

Plomp, Tjeerd dan Neinke Nieveen. 2013. Educational Design Research, Part A: An Introduction. Enchede: SLO

Tusaddiah, Halimah. 2012. Peningkatan Kemampuan Koneksi dan Representasi Matematis Peserta didik SMA melalui Pembelajaran Berbasis Mind Map.Thesis tidak diterbitkan. Bandung: Program Pascasarjana UPI. 